University of Nebraska - Lincoln

DigitalCommons@University of Nebraska - Lincoln

1982

New Plesiadapiform Primates From the Eocene of Wyoming and

Montana

Kenneth D. Rose

Johns Hopkins University, kdrose@jhmi.edu

Thomas M. Bown

U.S. Geological Survey

Follow this and additional works at: https://digitalcommons.unl.edu/usgsstaffpub

Part of the Earth Sciences Commons

Rose, Kenneth D. and Bown, Thomas M., "New Plesiadapiform Primates From the Eocene of Wyoming and Montana" (1982). USGS Staff -- Published Research. 203.

https://digitalcommons.unl.edu/usgsstaffpub/203

This Article is brought to you for free and open access by the US Geological Survey at DigitalCommons@University of Nebraska - Lincoln. It has been accepted for inclusion in USGS Staff -- Published Research by an authorized administrator of DigitalCommons@University of Nebraska - Lincoln. 


\title{
NEW PLESIADAPIFORM PRIMATES FROM THE EOCENE OF WYOMING AND MONTANA
}

\author{
KENNETH D. ROSE ${ }^{1}$ and THOMAS M. BOWN ${ }^{2}$ \\ ${ }^{1}$ Department of Cell Biology and Anatomy, Johns Hopkins University School of Medicine, Baltimore, Maryland 21205; \\ ${ }^{2}$ Paleontology-Stratigraphy Branch, U.S. Geological Survey, Denver, Colorado 80225
}

\begin{abstract}
Several recently discovered fossil specimens add to our knowledge of plesiadapiform primates. Micromomys willwoodensis, new species, is a diminutive microsyopid from the early Eocene (early Wasatchian) Willwood Formation of the Clark's Fork Basin, Wyoming. It is larger and more specialized than late Paleocene $M$. vossae and $M$. silvercouleei. Elwynella oreas is a new genus and species of paromomyid from the middle Eocene (early Bridgerian) Aycross Formation of northwestern Wyoming. It is most closely related to Phenacolemur, but differs from all other post-Tiffanian paromomyids in retention of $\mathrm{P}_{3}$ and in details of incisor morphology and molar trigonid structure. New specimens of the microsyopid Tinimomys graybulliensis are described, including a nearly complete dentary from the Wasatchian of the Bighorn Basin and the first record from probable Clarkforkian (latest Paleocene-earliest Eocene) beds of the Powder River Basin. The first Wasatchian specimen of Plesiadapis is described and illustrated.
\end{abstract}

\section{INTRODUCTION}

The last decade has witnessed a surge of interest and substantial advances in our understanding of the oldest primates, the archaic forms now generally grouped in the suborder Plesiadapiformes (see summaries by Simons, 1972; Szalay, 1972; Szalay and Delson, 1979; Rose and Fleagle, 1981). Nearly thirty new species-a third of all known plesiadapiforms (including microsyopids) - have been described during this period. Much has been added also to our knowledge of their anatomy, especially dental and cranial morphology, promoting a better understanding of their paleobiology. Plesiadapiforms represent a very diversified and highly successful radiation of mammals, particularly in western North America, where some species numbered among the most common mammals in middle and late Paleocene terrestrial vertebrate assemblages (Rose, 1981). Diversity and abundance of plesiadapiforms declined substantially by Wasatchian time, however, when they may have been largely replaced ecologically by adapid and omomyid primates and rodents.

In this paper we describe a new genus and species of paromomyid from the middle Eocene, a new species of microsyopid from the early Eocene, and other specimens that contribute new information on morphology or range of known taxa.

Dimensions are given in millimeters, measured to the nearest $0.05 \mathrm{~mm}$ using a reticle calibrated to twentieths of $\mathrm{mm}$ in one eyepiece of a binocular microscope.
Abbreviations-PU, Princeton University Museum of Natural History, Princeton, New Jersey; USGS, U.S. Geological Survey, Paleontology-Stratigraphy Branch (Vertebrate Paleontology), Denver, Colorado; USNM, Department of Paleobiology, National Museum of Natural History, Smithsonian Institution, Washington, D.C.; UW, University of Wyoming Museum of Geology, Laramie, Wyoming; L, maximum length; $B$, maximum breadth; a, approximate.

Acknowledgements-We are grateful to Drs. D. Baird (PU), R. J. Emry (USNM), and J. A. Lillegraven (UW) for permission to describe some of the specimens included here, and to D. W. Krause (University of Michigan) for providing a cast of Micromomys vossae. We have profited from discussions with $\mathrm{Mr}$. Krause, Dr. P. D. Gingerich, and Dr. R. F. Kay, and we thank Mr. Krause and Dr. Gingerich for helpful comments on the manuscript. The illustrations were expertly prepared by David Bichell and photographed by T. M. Urquhart. This study was supported by a grant from the John J. Hopkins Fund to KDR. TMB's research was conducted under the auspices of USGS Project 1-9590-02705.

\section{SYSTEMATIC PALEONTOLOGY \\ Suborder PLESIADAPIFORMES \\ Family MICROSYOPIDAE}

Micromomys and Tinimomys are very small, specialized plesiadapiforms characterized by hypertro- 
phy of $\mathrm{P}_{4}$. Because of their probable close relationship, Szalay (1974) placed them together in the tribe Micromomyini, which he allocated to the Paromomyidae. Our comparisons of these two genera with other Paleocene and Eocene primates indicate that they are more closely allied with the diminutive Torrejonian Palenochtha and Tiffanian Navajovius - considered paromomyids by Szalay but microsyopids by us (Bown and Rose, 1976) - than with any other forms. It is on this basis that we allocate Micromomys and Tinimomys to the Microsyopidae. Their precise position within that family will remain uncertain until more complete specimens are available. The resemblance between Tinimomys and Eocene uintasoricine microsyopids seems to be chiefly due to their small size and probably does not indicate particularly close relationship.

\section{MICROMOMYS Szalay, 1973}

MICROMOMYS WILLWOODENSIS, new species (Fig. 1)

Holotype-PU 17732, left dentary with $\mathrm{P}_{4}$, alveoli for $M_{1}$, and roots of $M_{2}$.

Hypodigm-Holotype only.

Horizon and Locality-Early Eocene (early Wasatchian) Willwood Formation, Princeton University Camp \#1 (1928) = University of Michigan Museum of Paleontology locality SC-2: NE $1 / 4$ Sec. 35 and SE $1 / 4$ Sec. 26, T. 56 N, R. 102 W, Park County (Bighorn Basin), Wyoming.

Diagnosis- $\mathrm{P}_{4}$ about 25\% larger than in $M$. silvercouleei and $M$. vossae; trigonid of $\mathrm{P}_{4}$ longer, broader, and taller than in those species; talonid slightly larger than in $M$. vossae, but about the same size as in $M$. silvercouleei. Molars (judging from alveoli) about same size as in $M$. silvercouleei and $M$. vossae.

Etymology-In allusion to the provenance of the holotype.

Description-The single known specimen contains only one tooth, $\mathrm{P}_{4}$, but this tooth is present also in the holotypes of the two Tiffanian species, $M$. silvercouleei (Fig. 2) and M. vossae; it is the most diagnostic tooth in these species, as in many other plesiadapiforms. $\mathrm{P}_{4}$ in $M$. willwoodensis is generally similar to its counterpart in the other two species. In all three it is the largest cheek tooth, distinctive for its high and pointed trigonid formed solely by the protoconid (metaconid and paraconid are absent), and its very small, basined talonid. In $M$. willwoodensis the paracristid of $\mathrm{P}_{4}$ descends anteriorly from the protoconid to meet a short, vertically oriented lingual crest, gently convex anteriorly, that forms a short lingual cingulum at the front of the trigonid. This feature is much less distinct on $\mathrm{P}_{4}$ of $M$. vossae and $M$. silvercouleei. $\mathrm{P}_{4}$ in the new species is distinctly larger and higher-crowned than in the Tiffanian species-about 20\% longer, $30 \%$ broader, and $15 \%$ taller than in $M$. silvercouleei, and about
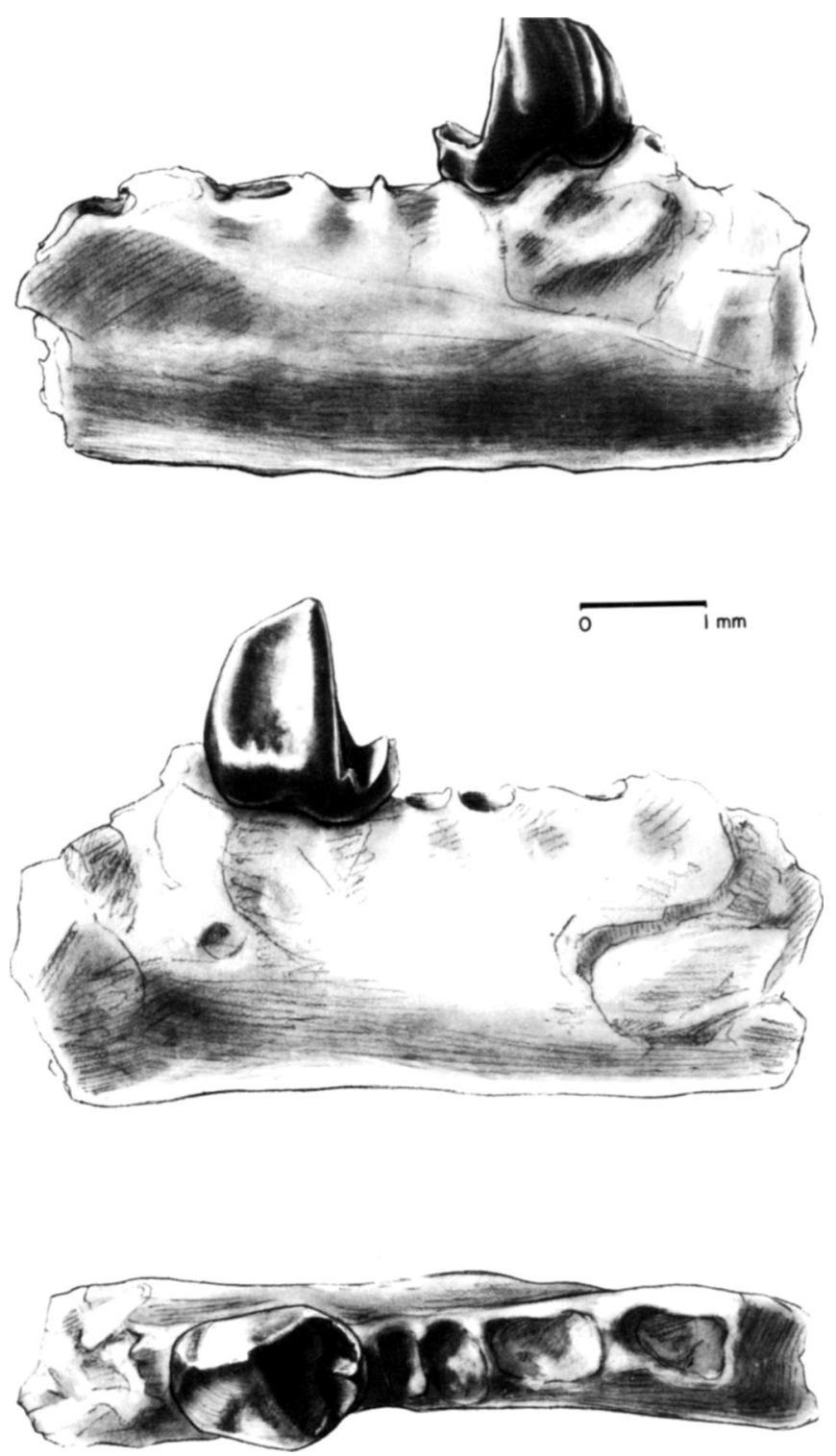

FIGURE 1. Micromomys willwoodensis, new species, holotype, PU 17732 , left dentary with $\mathrm{P}_{4}$. Top to bottom: lingual, buccal and occlusal views.

$20 \%$ longer, $60 \%$ broader, and $40 \%$ taller than in $M$. vossae. Most of this difference is attributable to enlargement of the trigonid, particularly inflation of its posterobuccal aspect. As in the two Tiffanian species, a deep hypoflexid separates the small talonid from the trigonid in $M$. willwoodensis, but its trigonid is so broad that in occlusal view the talonid basin occupies only the lingual half of the back of $\mathrm{P}_{4}$. This contrasts with $M$. vossae and, to a lesser extent, $M$. silvercouleei, in which the trigonid of $\mathrm{P}_{4}$ is not much broader than the talonid. The talonid basin in $M$. willwoodensis is surrounded by a continuous crest marked by only faint swellings in the positions of the hypoconid and the entoconid, very similar to the condition in $M$. silvercouleei. 

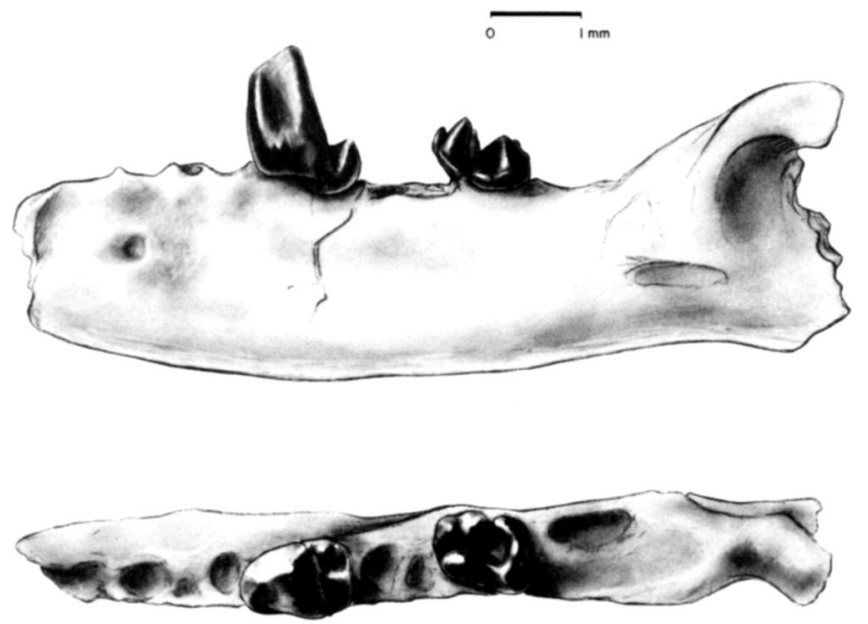

FIGURE 2. Micromomys silvercouleei, holotype, PU 17676, left dentary with $\mathrm{P}_{4}$ and $\mathrm{M}_{2}$, buccal and occlusal views.

Alveoli of the first two molars are preserved in the holotype of the new species, and they indicate that these teeth were much smaller than $\mathrm{P}_{4}$, about the same size as in other species of Micromomys, and that $\mathbf{M}_{1}$ may have been slightly larger than $\mathbf{M}_{2}$. Only part of the alveoli for $M_{3}$ is preserved, so the size of this tooth is not known.

Dimensions $(\mathrm{mm})$ of the holotype are: $\mathrm{P}_{4} \mathrm{~L}=1.70$, $\mathrm{P}_{4} \mathrm{~B}=1.30, \mathrm{P}_{4}$ height (labially) $=2.00$, depth of dentary (labially, below posterior root of $\mathrm{P}_{4}$ ) $=2.30$. In the type and only known specimen of $M$. silvercouleei, $\mathrm{P}_{4} \mathrm{~L}=1.40, \mathrm{P}_{4} \mathrm{~B}=1.00, \mathrm{P}_{4}$ height $=1.75$, dentary depth $=2.30$. (As noted by Dashzeveg and McKenna [1977], the dimensions of this specimen reported by Szalay [1973:79] are in error, although the scale in his figure is correct.) In the type of $M$. vossae, $\mathrm{P}_{4} \mathrm{~L}=1.30, \mathrm{P}_{4} \mathrm{~B}=0.80, \mathrm{P}_{4}$ height $=1.40$.

Discussion-Micromomys is one of the most poorly known genera of fossil primates. $M$. willwoodensis and the type species, $M$. silvercouleei, are each known from only a single fragmentary jaw, and only two specimens of $M$. vossae have been reported (Krause, 1978). Nonetheless, Micromomys is one of the most distinctive plesiadapiforms, and differences in size and shape of $\mathrm{P}_{4}$ support recognition of three species, an interpretation strengthened by their different stratigraphic levels. The holotype of $M$. silvercouleei Szalay (1973) is from the late Tiffanian Princeton Quarry (upper Polecat Bench Formation of Jepsen [1940]; Plesiadapis simonsi Zone of Gingerich [1975, 1976]), situtated about $18 \mathrm{~km}$ northeast and $950 \mathrm{~m}$ below (stratigraphically) the locality of $M$. willwoodensis. M. vossae Krause (1978) is the oldest species, from the late Tiffanian Roche Percée local fauna of southeastern Saskatchewan (Ravenscrag Formation, Plesiadapis churchilli Zone of Gingerich). The progressive hypertrophy of $\mathrm{P}_{4}$ in the sequence $M$. vossae-M. silvercouleei-M. willwoodensis suggests that the three species may be stages of a single lineage.

The new species thus extends the temporal range of Micromomys from late Tiffanian to early Wasatchian (no Clarkforkian representatives are known), making it approximately contemporary with its similar-sized relative Tinimomys graybulliensis. $M$ willwoodensis differs from $T$. graybulliensis in having a relatively larger $\mathrm{P}_{4}$ with a conspicuously taller trigonid and a relatively smaller talonid basin (see Fig. 3).

\section{TINIMOMYS Szalay, 1974}

\section{TINIMOMYS GRAYBULLIENSIS Szalay, 1974}

(Figs. 3, 4)

Szalay proposed this species on the basis of a maxillary fragment containing $\mathrm{P}^{4}-\mathrm{M}^{2}$ (holotype) and an incomplete dentary with $\mathrm{P}_{3-4}$, both from early Wasatchian strata (lower Willwood Formation) of the Bighorn Basin, Wyoming. Since his description, several additional specimens of Wasatchian and Clarkforkian age have been reported (Bown and Rose, 1976; Bown, 1979; Rose, 1981).

We illustrate here (Fig. 3) a nearly complete right dentary that comprises a part of the incisor, $\mathrm{P}_{4}-\mathrm{M}_{2}$, and alveoli for the anterior teeth and $\mathrm{M}_{3}$ (USGS 366, from USGS vertebrate locality D-1228 = UW locality V-73129, lower Willwood Formation, early Wasatchian, Bighorn Basin, Wyoming). It is of interest because it is one of the most complete known specimens of this species, its cheek teeth show almost no wear, and it reveals more of the incisor than any other specimen. The greatly enlarged incisor is very compressed laterally and very deep, occupying more than
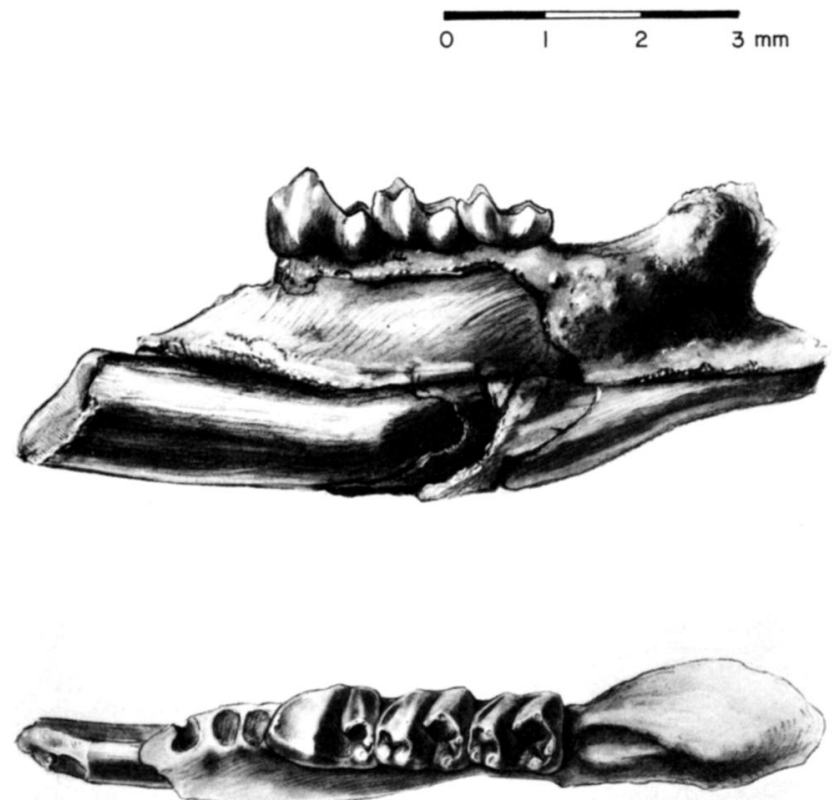

FIGURE 3. Tinimomys graybulliensis, USGS 366, right dentary with $\mathrm{P}_{4}-\mathrm{M}_{2}$ and part of incisor, lingual and occlusal views. 

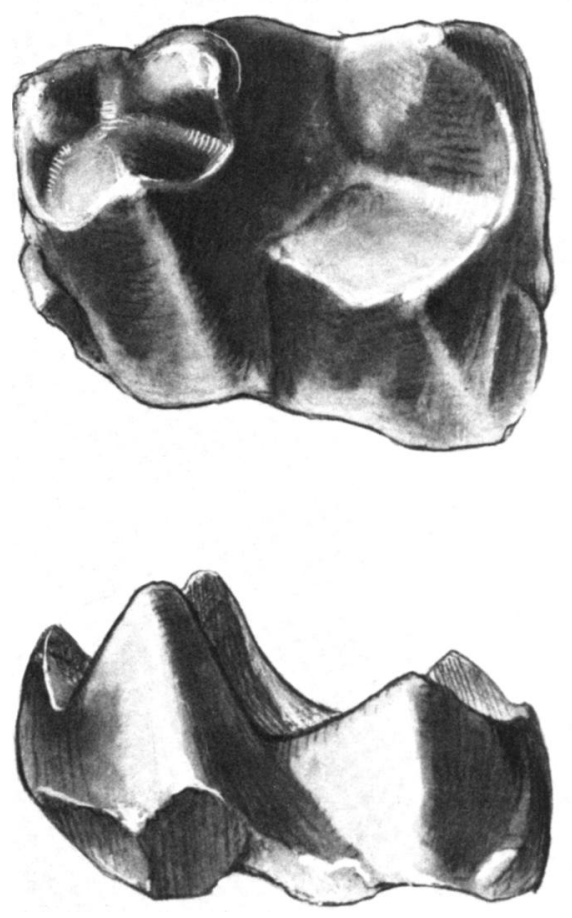

FIGURE 4. ?Tinimomys graybulliensis, USNM 299811, left $\mathrm{M}_{1}$, occlusal and buccal views.

half the depth of the dentary. The medial side of the jaw is damaged, thus revealing that the root of the incisor extends at least as far back as beneath $\mathrm{M}_{2}$. Between the incisor and $\mathrm{P}_{4}$ are three alveoli, which housed a single-rooted $\mathrm{P}_{2}\left(\right.$ ?) and the two-rooted $\mathrm{P}_{3}$ (preserved in other specimens), confirming that the lower dental formula of Tinimomys is probably 1.0.3.3 (Bown and Rose, 1976). Dimensions of USGS 366 are: incisor, mediolateral breadth $=0.70$, depth $=1.70 ; \mathrm{P}_{4} \mathrm{~L}=1.40, \mathrm{P}_{4} \mathrm{~B}=1.10 ; \mathrm{M}_{1} \mathrm{~L}=1.20, \mathrm{M}_{1} \mathrm{~B}$ $=1.10 ; \mathrm{M}_{2} \mathrm{~L}=1.20, \mathrm{M}_{2} \mathrm{~B}=1.05$; depth of dentary (labially, under posterior root of $\mathrm{P}_{4}$ ) $=2.90$.

An isolated unworn lower molar (USNM 299811, left $\mathrm{M}_{1}$ : Fig. 4) recently discovered in a screenwashed sample from the northern Powder River Basin (Sec. 34, T. 9 S, R. 43 E, Big Horn County, Montana) may be the first representative of Tinimomys graybulliensis from this basin. It is from the lower part of what has been called the Wasatch Formation (but see Delson, 1971), about 40 feet above the Fort Union-Wasatch contact-stratigraphically much lower than the Powder River local fauna of early Wasatchian age (Delson, 1971). The only other mammalian specimens associated with this tooth are isolated teeth of a small plagiomenid, closest to the Clarkforkian species Plagiomene accola and Planete- therium mirabile (Rose, 1981). Hence a Clarkforkian age for USNM 299811 is probable. The tooth is very small $(\mathrm{L}=1.25, \mathrm{~B}=1.05)$ and is characterized by distinct trigonid cusps and a broad, deeply basined talónid, as in T. graybulliensis. Compared to other specimens of this species, USNM 299811 has slightly more acute and more splayed trigonid cusps, a more deeply incised notch between the paraconid and the metaconid, and a higher hypoconid. These differences do not seem sufficient, however, to preclude tentative assignment of the specimen to $T$. graybulliensis.

\section{Family PlesiadaPIDAE \\ PLESIADAPIS Gervais, 1877}

\section{PLESIADAPIS DUBIUS (Matthew, 1915)}

(Fig. 5)

A fragmentary left maxilla with $\mathrm{P}^{4}-\mathrm{M}^{1}$ and roots of $\mathrm{P}^{2-3}$ (UW 6118, found by the junior author at UW locality V-73003=Yale-Michigan locality 418, SW $1 / 4$ Sec. 35, T. 54 N, R. 97 W, Coon Creek area, Big Horn County, Wyoming; Willwood Formation) is the only known specimen of Plesiadapis from strata of undoubted early Wasatchian age. The morphology of $\mathrm{P}^{4}$ and $\mathrm{M}^{1}$ is unmistakably that of Plesiadapis, and the size is appropriate for $P$. dubius, the latestsurviving species of Plesiadapis known from North America. $\mathrm{P}^{4}$ is submolariform, with closely appressed paracone and metacone, a small parastyle, a large protocone, and a well developed paraconule. The paraconule approaches the size of that in middle Tiffanian $P$. rex and in some specimens of late Tiffanian $P$. fodinatus, rather than being small or absent, as is typical in P. dubius (Gingerich, 1976). However, this feature is known to vary in species of Plesiadapis. In other respects the specimen is indistinguishable from $P$. dubius. Dimensions of UW 6118 are: $\mathrm{P}^{4} \mathrm{~L}=2.40, \mathrm{P}^{4} \mathrm{~B}=3.70, \mathrm{M}^{1} \mathrm{~L}=3.00, \mathrm{M}^{1} \mathrm{~B}=4.10$.

This specimen is the first evidence that Plesiadapidae persisted in North America beyond the close of Clarkforkian time. Although Gingerich (1976) included UW 6118 in his hypodigm of Plesiadapis

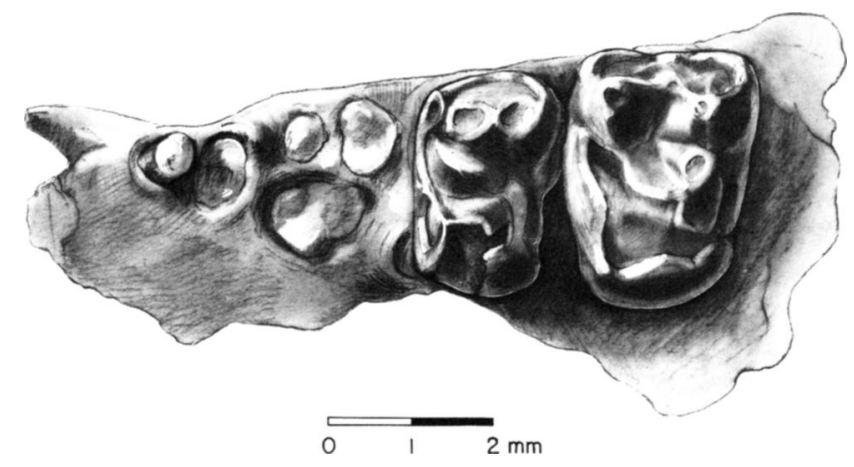

FIGURE 5.Plesiadapis dubius, UW 6118, left maxilla with $\mathrm{P}^{4}-\mathrm{M}^{1}$. Protocones of both are heavily worn and slightly damaged. 
dubius, he did not explicitly mention its early Wasatchian age; but this is affirmed by its association with the perissodactyl Hyracotherium and the adapid primate Pelycodus, both indicators of Wasatchian age (Rose, 1980, 1981). Previous reports of Wasatchian ("Gray Bull") Plesiadapis by Van Houten (1945) and Wood (1967) have been confuted by Gingerich (1976); rather, those specimens are Clarkforkian in age.

\section{Family Paromomyidae}

\section{ELWYNELLA, new genus}

Type Species-Elwynella oreas sp. nov., only known species.

Distribution-Middle Eocene (early Bridgerian) of northwestern Wyoming.

Diagnosis-Medium-sized paromomyid, about the size of Phenacolemur jepseni. Lower dental formula 1.0.2.3. Differs from all other post-Tiffanian paromomyids in retaining $\mathrm{P}_{3}$, which is single-rooted rather than double-rooted as in Paromomys, Ignacius fremontensis, and some I. frugivorus. Very short diastema between incisor and $P_{3}$. Dorsal aspect of dentary between incisor and premolars gently rounded, not laterally constricted and cristate as in Phenacolemur and Ignacius (except I. fremontensis), and without labial depression characteristic of those genera. Lower incisor long and slender, but broader than in Phenacolemur and Ignacius. Lower molars with well defined crests and relatively deep talonid basins as in Phenacolemur, not with low relief as in Ignacius; trigonids inclined anteriorly, paracristids sharply arcuate. Paraconid small or absent on $\mathbf{M}_{1}$ and absent on $\mathrm{M}_{2}$, in contrast to all other paromomyids except Phenacolemur jepseni.

Etymology-For Elwyn L. Simons, eminent student of primate evolution.

\section{ELWYNELLA OREAS, new species}

(Fig. 6)

Cf. Phenacolemur sp., Bown, 1982.

Holotype-USGS 2351, right dentary with incisor, $\mathrm{M}_{1-2}$, and alveoli for $\mathrm{P}_{3-4}$ and $\mathrm{M}_{3}$.

Hypodigm-Holotype and USGS nos. 2354 (right $\mathrm{M}_{1}$ ) and 2355 (right $\mathrm{M}_{2}$ ).

Horizon and Locality-Middle Eocene (early Bridgerian), lower part of Aycross Formation, USGS fossil vertebrate locality D-1034: Vass Quarry, Sec. 33, T. 44 N, R. 100 W, Hot Springs County, Wyoming.

Diagnosis-As for genus.

Etymology-Latin oreas, a mountain nymph; with reference to the present-day location of Vass Quarry, in the Absaroka Mountains, and its former elevation well above the Tertiary basin floor.

Description-The holotype of Elwynella oreas is a nearly complete dentary, which most closely resembles Wasatchian Phenacolemur jepseni (San José Formation, New Mexico: Simpson, 1955) in molar morphology. It differs importantly from the latter, however, in the retention of an alveolus for $\mathrm{P}_{3}$, a tooth lost in all known species of Phenacolemur and in all Ignacius after the middle Tiffanian. The alveolus indicates a single-rooted $\mathrm{P}_{3}$ of moderate size, not substantially reduced as in many other plesiadapiforms. A very short diastema separates $P_{3}$ from the base of the enlarged incisor. There is no room for the concavity on the labial side of the diastema that is characteristic of the dentaries of Phenacolemur and most Ignacius, nor is the dorsal surface of the jaw in this region crest-like as in those genera. $\mathrm{P}_{4}$ was tworooted and, judging from its alveoli, longer than $M_{1}$.

The molars have sharply defined crests and well developed basins. Paraconids are absent on $\mathbf{M}_{1}$ and $\mathrm{M}_{2}$ in the holotype, and the paracristids are arcuate, hence in occlusal view the trigonids (especially on $\mathbf{M}_{1}$ ) are semicircular in form. A small paraconid is present in USGS $2354\left(\mathrm{M}_{1}\right)$. Thus the molars resemble those of Phenacolemur rather than those of Ignacius, and they are particularly similar to those of $P$. jepseni.

The lower incisor exhibits a combination of features characteristic of Phenacolemur on one hand and Microsyops on the other. It is very long and relatively slender, as in Phenacolemur, but broader (especially in its midsection) than in the latter. Long dorsolateral and ventromedial cristids extend from the tip of the crown nearly to its base, as in Microsyops and some Phenacolemur. The surface between these crests faces dorsomedially. It is convex centrally and excavated parallel to each cristid (more so inferiorly). In these features the incisor resembles those of Plesiolestes and Microsyops more than that of Phenacolemur, but it is much longer and not so deep as in the former genera. It is also very reminiscent of the incisor in apatemyids such as Labidolemur (see West, 1973), but it is less recurved and lacks the serrated dorsolateral margin characteristic of apatemyids.

The dentary in the holotype of $E$. oreas is shallower than in many specimens of Phenacolemur and Ignacius, in this regard also resembling the apatemyids Labidolemur and Jepsenella.

Dimensions of the holotype are: incisor length (laterally, from alveolar border to tip of crown) = $10.0 \mathrm{a}$, incisor depth at alveolar border $=2.40$, incisor breadth (maximum) $=1.6 \mathrm{a} ; \mathrm{M}_{1} \mathrm{~L}=2.55, \mathrm{M}_{1} \mathrm{~B}=$ $1.90 ; \mathrm{M}_{2} \mathrm{~L}=2.60, \mathrm{M}_{2} \mathrm{~B}=2.10$; dentary depth (buccal side below center of $\mathrm{M}_{1}$ ) $=5.20$. Measurements for the referred specimens are: USGS 2354, $\mathrm{M}_{1} \mathrm{~L}=2.40$, $\mathrm{M}_{1} \mathrm{~B}=1.80$; USGS 2355, $\mathrm{M}_{2} \mathrm{~L}=2.50, \mathrm{M}_{2} \mathrm{~B}=2.00$.

Discussion-Bown (1982) described two lower molars (cf. Phenacolemur sp.) from the Aycross Formation, then the only known middle Eocene paromomyids. Recognition that these specimens actually belong to a new genus has come with the discovery of a nearly complete dentary preserving similar molars, but with incisor morphology and dental formula 

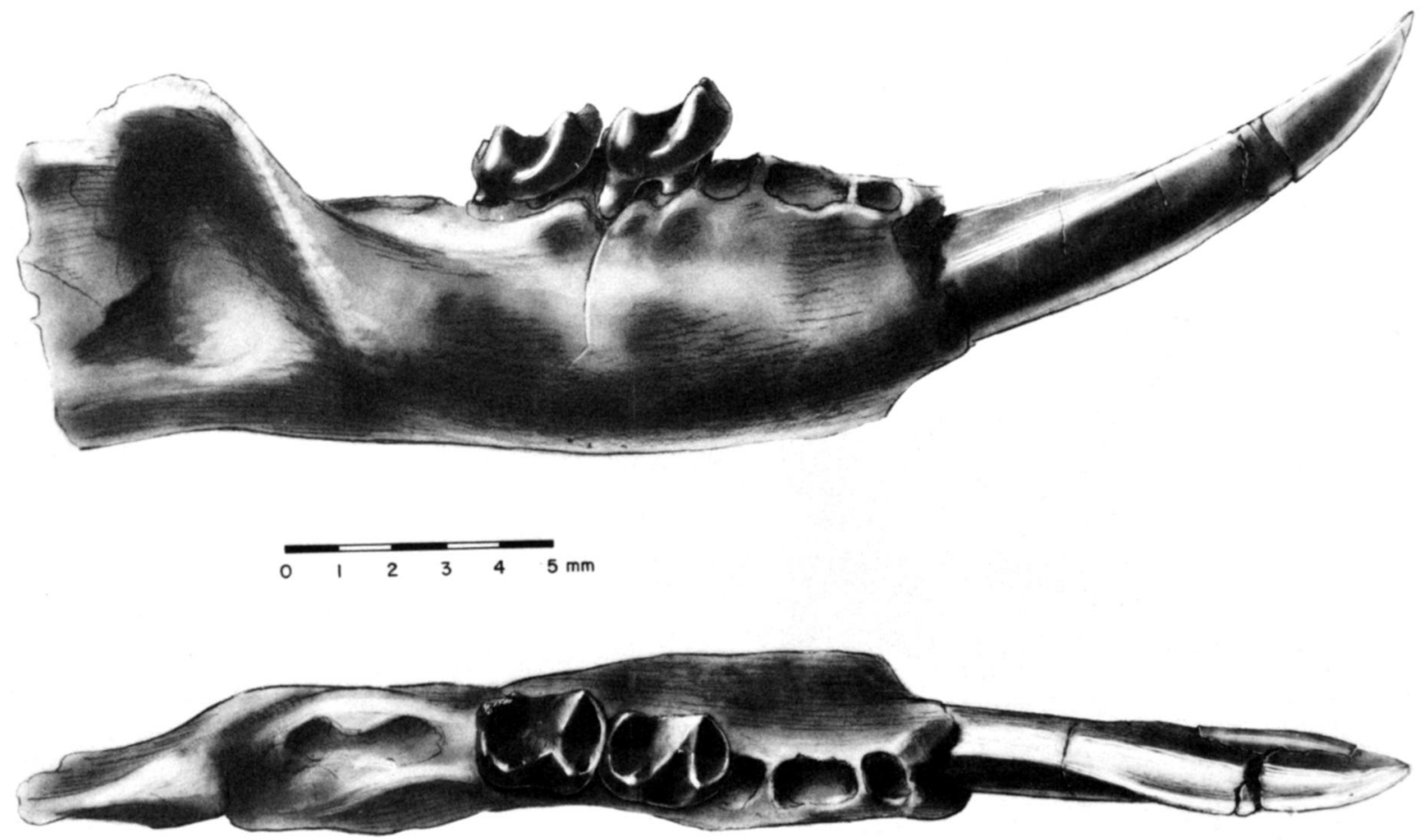

FIGURE 6. Elwynella oreas, new genus and species, holotype, USGS 2351, right dentary with incisor and $\mathbf{M}_{1}-\mathrm{M}_{2}$, buccal and occlusal views.

differing from those of Phenacolemur. The only known younger paromomyids are Ignacius mcgrewi (Robinson, 1968) and Phenacolemur shifrae (Krishtalka, 1978), both represented only by isolated teeth from upper Eocene rocks along Badwater Creek, Wind River Basin, Wyoming.

Elwynella is the only Eocene paromomyid that is known to possess $\mathrm{P}_{3}$. Indeed, $\mathrm{P}_{3}$ is present only in Paromomys (Torrejonian) and in the earliest species of Ignacius (I. fremontensis and possibly some I. frugivorus, late Torrejonian-middle Tiffanian); it is already absent in the earliest species of Phenacolemur ( $P$. pagei, late Tiffanian-Clarkforkian). The presence of $\mathrm{P}_{3}$ in a form otherwise so derived in molar and incisor morphology justifies its generic separation from other paromomyids. Although in its molar structure (which is clearly advanced for paromomyids) Elwynella oreas closely resembles Phenacolemur jepseni, the association of this trait with the primitive retention of $\mathrm{P}_{3}$ suggests that Elwynella represents a separate lineage, evolving in parallel with Phenacolemur and derived from an ancestor (in common with Phenacolemur) that had not yet lost $\mathrm{P}_{3}$. If this hypothesis is correct, Elwynella must have diverged from other paromomyids during the Tiffanian.

\section{COMPOSITION OF THE PLESIADAPIFORMES}

There is a general consensus that the families Plesiadapidae, Carpolestidae, Saxonellidae, Paromomyidae, and (questionably) Picrodontidae belong in the suborder Plesiadapiformes. No such agreement, however, applies to the systematic position or the composition of the Microsyopidae. Based on dental evidence elaborated elsewhere (Bown and Gingerich, 1973; Bown and Rose, 1976; Gingerich, 1976; Bown, 1979), we include the Microsyopidae in the Plesiadapiformes, an assignment that has been disputed by Szalay (1972) and Szalay and Delson (1979).

The issue of microsyopid affinities has been complicated by controversy over the systematic position of several genera-middle Paleocene Palaechthon (and the closely allied or synonymous Plesiolestes, Talpohenach, and Torrejonia) and Palenochtha, late Paleocene Navajovius and Berruvius, late Paleocene-early Eocene Micromomys, and early Eocene Tinimomys-considered to be paromomyids by many authors, who would restrict the Microsyopidae to Eocene Microsyops, Craseops, Niptomomys, and Uintasorex. The molar morphology of these controversial taxa is considerably more conservative 
than in paromomyids sensu stricto (Paromomys, Ignacius, Phenacolemur, and Elwynella). They have generally higher-crowned molars with more acute cusps, less compressed trigonids, and less reduced paraconids than other plesiadapiforms. These primitive features are coupled with a relatively specialized, elongate, procumbent incisor with a lanceolate crown, foreshadowing that characteristic of Eocene microsyopids. Our tentative assignment of these genera to the Microsyopidae (Bown and Rose, 1976) reflects these dental similarities. Basicrania or associated skeletal elements, which would surely provide additional clues to their affinities, are not known for any of the controversial taxa. Until such evidence is available, their relationships will remain moot.

The Microsyopidae, as viewed here, is a family consisting of the most conservative plesiadapiforms, which are, therefore, associated largely by symplesiomorphic characters. Such an association seems unavoidable given our present state of knowledge. Each other plesiadapiform family is a closely knit group of genera with its own distinctive derived traits. Alliance of Palaechthon and its allies with the Microsyopidae can be defended on dental grounds outlined above, and it has the additional advantage of making the Paromomyidae a closely unified, surely monophyletic family.

\section{REFERENCES}

Bown, T. M. 1979. Geology and mammalian paleontology of the Sand Creek Facies, Lower Willwood Formation (lower Eocene), Washakie County, Wyoming. Wyoming Geological Survey, Memoir 2:1-151.

1982. Geology, paleontology, and correlation of Eocene volcaniclastic rocks, southeast Absaroka Range, Hot Springs County, Wyoming. U. S. Geological Survey, Professional Paper 1201-A:1-75.

and Gingerich, P. D. 1973. The Paleocene primate Plesiolestes and the origin of Microsyopidae. Folia primatologica 19:1-8.

- and Rose, K. D. 1976. New early Tertiary primates and a reappraisal of some Plesiadapiformes. Folia primatologica 26:109-138.

Dashzeveg, D. and McKenna, M. C. 1977. Tarsioid primate from the early Tertiary of the Mongolian People's Republic. Acta palaeontologica Polonica 22:119-137.

Delson, E. 1971. Fossil mammals of the early Wasatchian Powder River local fauna, Eocene of northeast Wyoming. American Museum of Natural History, Bulletin 146:305-364.

Gingerich, P. D. 1975. New North American Plesiadapidae (Mammalia, Primates) and a biostratigraphic zona- tion of the middle and upper Paleocene. University of Michigan, Contributions from the Museum of Paleontology 24:135-148.

1976. Cranial anatomy and evolution of early Tertiary Plesiadapidae (Mammalia, Primates). University of Michigan, Papers on Paleontology 15:1-141.

Jepsen, G. L. 1940. Paleocene faunas of the Polecat Bench Formation, Park County, Wyoming. Part I. American Philosophical Society, Proceedings 83:217-341.

Krause, D. W. 1978. Paleocene primates from western Canada. Canadian Journal of Earth Sciences 15:1250 1271.

Krishtalka, L. 1978. Paleontology and geology of the Badwater Creek area, central Wyoming. Part 15: Review of the late Eocene primates from Wyoming and Utah, and the Plesitarsiiformes. Annals of Carnegie Museum 47:335-360.

Robinson, P. 1968. The paleontology and geology of the Badwater Creek area, central Wyoming. Part 4: Late Eocene primates from Badwater, Wyoming, with a discussion of material from Utah. Annals of Carnegie Museum 39:307-326.

Rose, K. D. 1980. Clarkforkian Land-Mammal Age: revised definition, zonation, and tentative intercontinental correlations. Science 208:744-746.

-1981. The Clarkforkian Land-Mammal Age and mammalian faunal composition across the PaleoceneEocene boundary. University of Michigan, Papers on Paleontology 26:1-197.

and Fleagle, J. G. 1981. The fossil history of nonhuman primates in the Americas; pp. 111-167 in Coimbra-Filho, A. F. and Mittermeier, R. A. (eds.), Ecology and Behavior of Neotropical Primates, vol. 1. Academia Brasileira de Ciências, Rio de Janeiro.

Simons, E. L. 1972. Primate Evolution. Macmillan, New York, $322 \mathrm{pp}$.

Simpson, G. G. 1955. The Phenacolemuridae, new family of early primates. American Museum of Natural History, Bulletin 105:411-442.

Szalay, F. S. 1972. Paleobiology of the earliest primates; pp. 3-35 in Tuttle, R. (ed.), The Functional and Evolutionary Biology of Primates. Aldine, Chicago.

-1973. New Paleocene primates and a diagnosis of the new suborder Paromomyiformes. Folia primatologica 19:73-87.

-1974. A new species and genus of early Eocene primate from North America. Folia primatologica $22: 243-250$.

and Delson, E. 1979. Evolutionary History of the Primates. Academic Press, New York, 580 pp.

Van Houten, F. B. 1945. Review of latest Paleocene and early Eocene mammalian faunas. Journal of Paleontology 19:421-461.

West, R. M. 1973. Antemolar dentitions of the Paleocene apatemyid insectivorans Jepsenella and Labidolemur. Journal of Mammalogy 54:33-40.

Wood, R. C. 1967. A review of the Clark Fork vertebrate fauna. Breviora 257:1-30. 